\title{
Influence of temperature on hexose transport by round spermatids of rats
}

\author{
P. F. Hall and M. Nakamura \\ The Worcester Foundation for Experimental Biology, 222 Maple Avenue, Shrewsbury, \\ Massachusetts 01545, U.S.A.
}

\begin{abstract}
Summary. Transport of 3-O-methyl-D- $\left[{ }^{14} \mathrm{C}\right]$ glucose in vitro by round spermatids was more rapid at 34 than at $37^{\circ} \mathrm{C}$ and more rapid at 37 than at $40^{\circ} \mathrm{C}$. The difference between values at 34 and at $37^{\circ} \mathrm{C}$ was reversed by changing the spermatids from 37 to $34^{\circ} \mathrm{C}$ at various times during a total incubation of $1 \mathrm{~h}$. The effect of $37^{\circ} \mathrm{C}$ relative to $34^{\circ} \mathrm{C}$ was exerted on $K_{\mathrm{m}}$ for the transport process; $V_{\max }$ was unaltered. Inhibition by $37^{\circ} \mathrm{C}$ relative to $34^{\circ} \mathrm{C}$ was exerted on influx; efflux was the same at both temperatures. A fraction of cells from rat testis enriched in spermatocytes but free from spermatids showed greater transport at 37 than at $34^{\circ} \mathrm{C}$. These results indicate that one metabolic effect of body temperature $\left(37^{\circ} \mathrm{C}\right)$ as opposed to scrotal temperature $\left(34^{\circ} \mathrm{C}\right)$ is inhibition of glucose transport into round spermatids. This may contribute to the defective spermatogenesis that can occur in abdominal testes.
\end{abstract}

\section{Introduction}

Hexose transport appears to be rate-limiting for energy metabolism in some tissues (Elbrink \& Bihler, 1975) and dependence of the testes on glucose as a metabolic substrate is well known (Waites \& Setchell, 1964; Paul, Paul, Kopko, Bender \& Everett, 1953). The importance of glucose transport in bovine spermatozoa has been shown (Hupakka \& Hammerstedt, 1978), and spermatid metabolism is also known to be dependent upon temperature because several metabolic activities proceed more rapidly at 34 than at $37^{\circ} \mathrm{C}$ (Nakamura \& Hall, 1978). The spermatid appears to be the major cell type requiring scrotal $\left(34^{\circ} \mathrm{C}\right.$ in the rat) rather than body temperature $\left(37^{\circ} \mathrm{C}\right)$ for normal function and survival (Davis \& Firlit, 1963; Nakamura \& Hall, 1976). The following studies were undertaken to investigate the influence of temperature on the transport of a glucose analogue (3-O-methyl-D- $\left[{ }^{14} \mathrm{C}\right.$ glucose) by round spermatids of the rat.

\section{Materials and Methods}

Preparation of cells. Round (immature) spermatids were prepared by centrifugal elutriation and characterized as described elsewhere (Nakamura \& Hall, 1978). These cells were prepared from rats aged 35 days. During the preparation of spermatids, the cells were kept at $4^{\circ} \mathrm{C}$. One preparation of cells requires $1.5 \mathrm{~h}$. The purity of the final preparation of round spermatids was 93-95\% as judged by phase-contrast microscopy. Four rats (8 testes) were used for each preparation of cells.

Incubation. Spermatids were incubated in phosphate-buffered saline $(\mathrm{pH} \mathrm{7.4)}$ at the temperatures indicated in the text. Unless otherwise stated, the duration of incubation was $1 \mathrm{~h}$. 


\section{Measurement of transport of the glucose analogue}

The analogue used was 3-O-methyl-D- $\left[{ }^{14} \mathrm{C}\right]$ glucose (sp. act. $50 \mu \mathrm{Ci} / \mu \mathrm{mol}$ : NEC 377), and three methods of measuring transport were used.

Filtration. Following incubation, cells were diluted to $5 \mathrm{ml}$ with ice-cold phosphate-buffered saline ( $\mathrm{pH} \mathrm{7.4)}$ and poured onto a filter with a $1.2 \mu \mathrm{m}$ pore size (Gelman Instrument Co., Ann Arbor, Michigan). Buffer was removed by suction and the filtrate was washed twice with ice-cold buffer $(5 \mathrm{ml})$. These procedures required approximately $30 \mathrm{sec}$. Filters were air-dried and placed in $10 \mathrm{ml}$ scintillation fluid for determination of radioactivity (Hall \& Koritz, 1964).

Centrifugation with silicone oil. Aliquots of the cell suspension were layered (after incubation) onto discontinuous gradients prepared by layering the following three solutions in $0.4 \mathrm{ml}$ polyethylene microcentrifuge tubes (bottom to top): FS-1265 (10 $\mu \mathrm{l})$ (Dow Corning, Midland, Michigan): Triton X-100 (1\% w/v) (Sigma Chemical Corporation, St Louis, Missouri) in an aqueous sucrose solution $(20 \% \mathrm{w} / \mathrm{v})(10 \mu \mathrm{l})$ : Versilube F-50 (100 $\mu \mathrm{l}$ : Gelman). The gradient was centrifuged for $30 \mathrm{sec}$ in a Beckman microfuge B. The tubes were immersed in liquid nitrogen and the opaque layer (Triton-sucrose) containing the spermatids was cut and digested for $2 \mathrm{~h}$ at room temperature with $0.1 \mathrm{ml}$ Protosol (New England Nuclear, Boston, Massachusetts). The digested sample was subjected to liquid scintillation spectrometry. Extracellular radioactivity was determined by measuring extracellular fluid volume with $\left[{ }^{14} \mathrm{C}\right.$ linulin in identical samples run in duplicate with each experiment. The extracellular fluid volume varied less than $5 \%$ from one experiment to another. Values for transport were corrected for extracellular radioactivity.

Centrifugation and perchloric acid. Spermatids were diluted to $5 \mathrm{ml}$ with phosphate-buffered saline $\left(0^{\circ} \mathrm{C}\right)$ and sedimented by centrifugation at $600 \mathrm{~g}$ for $5 \mathrm{~min}$ at $4^{\circ} \mathrm{C}$ immediately after incubation. The cells were washed twice with cold buffer and sedimented again before homogenization in $2 \mathrm{ml} \mathrm{10 \%}(\mathrm{w} / \mathrm{v})$ aqueous perchloric acid. The homogenate was centrifuged at $900 \mathrm{~g}$ for $10 \mathrm{~min}$ and an aliquot of the supernate was subjected to liquid scintillation spectrometry.

Unless otherwise indicated, transport of 3-O-methyl-D- $\left[{ }^{14} \mathrm{C}\right]$ glucose was measured in $0.3 \mathrm{ml}$ phosphate-buffered saline ( $\mathrm{pH} 7.4$ ), using $0.1 \mu \mathrm{Ci}(1 \mathrm{mM})$ hexose (final concentration) in a metabolic shaker. Transport of glucose was measured exactly as described by Brooks (1979).

Spermatocytes. A fraction enriched in spermatocytes (S value $13.1(\mathrm{~mm} / \mathrm{h} \times \mathrm{g})^{2}$ was prepared by centrifugal elutriation (Nakamura \& Hall, 1976).

Influx and efflux. Influx of 3-O-methyl-D- $\left[{ }^{14} \mathrm{C}\right.$ glucose was determined by incubation for short periods during which efflux is small. Efflux was determined by incubating spermatids with 3-O-methyl-D- $\left[{ }^{14} \mathrm{C}\right.$ lglucose for $30 \mathrm{~min}$ at $34^{\circ} \mathrm{C}$. The cells were quickly centrifuged at $4{ }^{\circ} \mathrm{C}$ and re-suspended in the same volume of phosphate buffered saline ( $\mathrm{pH} 7.4$ ) without 3-Omethyl-D- $\left[{ }^{14} \mathrm{C}\right]$ glucose. The cells were then incubated at 34 or $37^{\circ} \mathrm{C}$. Samples of medium were taken at various times for determinations of ${ }^{14} \mathrm{C}$ by liquid scintillation spectrometry (Hall \& Koritz, 1964).

\section{Results}

\section{General characteristics of transport of 3-O-methyl-D-[ $\left[{ }^{14} \mathrm{C}\right]$ glucose}

The glucose analogue was taken up by round spermatids to give, at steady state, a tissue to medium ratio of $3.1 \pm 0.4$ (mean and range of 8 determinations). Steady state was reached between 60 and $90 \mathrm{~min}$. The total uptake of 3-O-methyl-D-[ ${ }^{14} \mathrm{C}$ lglucose was $48.2 \pm 3.4$ $\mathrm{nmol} / 10^{6}$ cells (mean and range for 8 observations using the centrifugation-perchloric acid method). When antimycin A $(0.1 \mathrm{~mm}$, Sigma) or rutamycin (20 $\mu \mathrm{M}$, Sigma), was added to the 
medium, active transport was abolished and the tissue:medium ratio remained at $1 \cdot 1 \pm 0.3$ and $0.97 \pm 0.4$ respectively (mean and range of 3 determinations). Measurements of uptake of 3-O-methyl-D- $\left[{ }^{14} \mathrm{C}\right.$ glucose by centrifugation into silicone oil were within $5 \%$ of the values obtained with perchloric acid, but values obtained by the filtration method were always significantly lower due to cell damage which could be seen by light microscopy. The data reported below were all obtained by the centrifugation-perchloric acid method, although the major conclusions were confirmed by the silicone oil method; these latter experiments are not shown here.

The glucose uptake by round spermatids in the presence and absence of 3-O-methylD-glucose (Sigma) is shown in Text-fig. 1. Glucose uptake as a function of substrate concentration showed a plateau (saturation kinetics) and 3-O-methyl-D-glucose acted as a competitive inhibitor of this process ( $K_{\mathrm{m}}$ increased; $V_{\max }$ unaltered). The $K$ for inhibition by 3-O-methyl-Dglucose was $21 \mathrm{~mm}$.

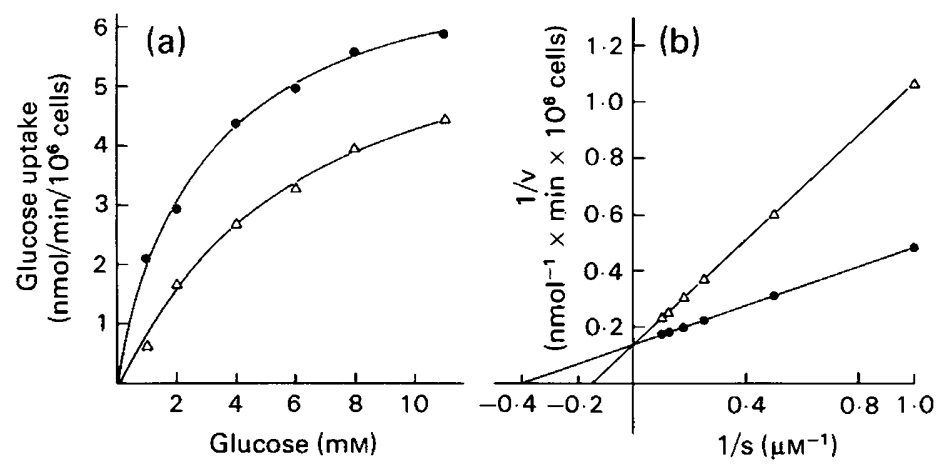

Text-fig. 1. (a) Competitive inhibition of glucose transport into round spermatids by 3-O-methyl-D-glucose $(20 \mathrm{~mm})$. The cells $\left(10^{6} / \mathrm{flask}\right)$ were incubated for $30 \mathrm{~min}$ in phosphatebuffered saline. Glucose transport was measured as described by Brooks (1979). (b) Double reciprocal plot of the data.

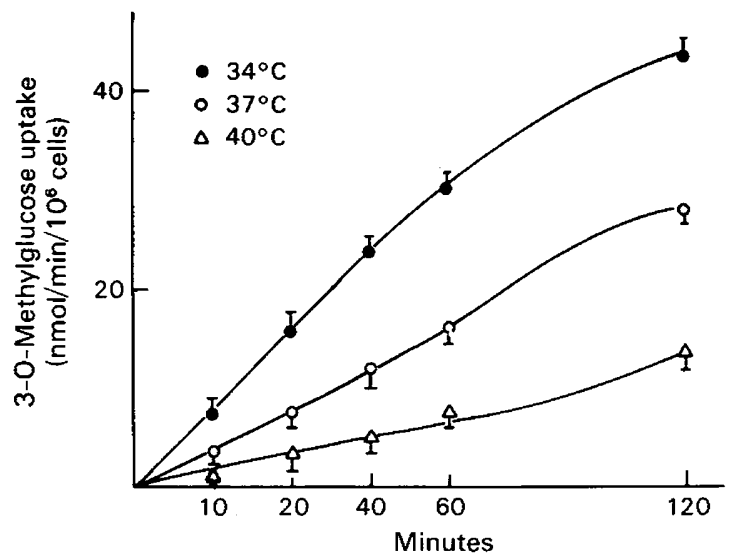

Text-fig. 2. Transport of 3-O-methyl-D-[ $\left[{ }^{14} \mathrm{C}\right]$ glucose by round spermatids at three different temperatures. Round spermatids $\left(10^{6}\right.$ cells/flask $)$ were incubated with 3-O-methyl-D$\left[{ }^{14} \mathrm{C}\right.$ ]glucose $\left(10^{5}\right.$ c.p.m.: $\left.0.1 \mathrm{~mm}\right)$, washed and homogenized in perchloric acid (see 'Materials and Methods'). The values shown are means and ranges for duplicate determinations. 


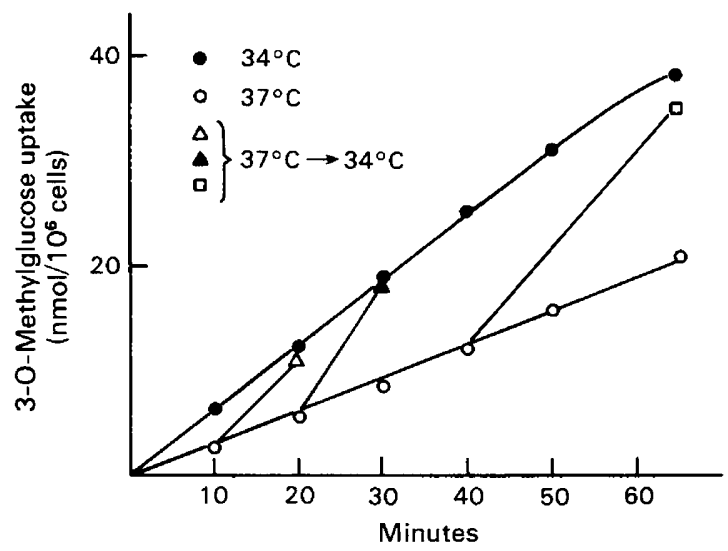

Text-fig. 3. Reversibility of the effect of temperature on transport of 3-O-methyl-D- $\left[{ }^{14} \mathrm{C}\right]$ glucose by round spermatids. The values shown are means and ranges for duplicate determinations.

\section{Effect of temperature on transport of 3-O-methyl-D- $\left[{ }^{14} C\right]$ glucose by spermatids}

As shown in Text-fig. 2, transport of 3-O-methyl-D- $\left[{ }^{14} \mathrm{C}\right]$ glucose was greater at 34 than at $37^{\circ} \mathrm{C}$ and greater at 37 than at $40^{\circ} \mathrm{C}$. Uptake was linear for at least 40 min. When spermatids were transferred from 37 to $34^{\circ} \mathrm{C}$ after various times at $37^{\circ} \mathrm{C}$, the rate of transport increased (Text-fig. 3). After incubations of 10 and $20 \mathrm{~min}$ at $37^{\circ} \mathrm{C}$, transport returned to values seen with cells incubated at $34^{\circ} \mathrm{C}$ throughout; after $40 \mathrm{~min}$ incubation at $37^{\circ} \mathrm{C}$ the rate of transport at $34^{\circ} \mathrm{C}$ increased (slope) but total uptake did not reach the values seen with cells incubated at $34^{\circ} \mathrm{C}$ throughout. The uptake of the glucose analogue was accelerated beyond control level (i.e. $34^{\circ} \mathrm{C}$ throughout) when the cells were transferred from 37 to $34^{\circ} \mathrm{C}$ but this cannot be explained at present.

\section{Kinetics of transport}

The results in Text-fig. 4 show that the effect of temperature was exerted on $K_{\mathrm{m}}$ rather than $V_{\max }$. The $K_{\mathrm{m}}$ values for the transport were $33 \mu \mathrm{M}$ at $34^{\circ} \mathrm{C}$ and $65 \mu \mathrm{M}$ at $37^{\circ} \mathrm{C}$.

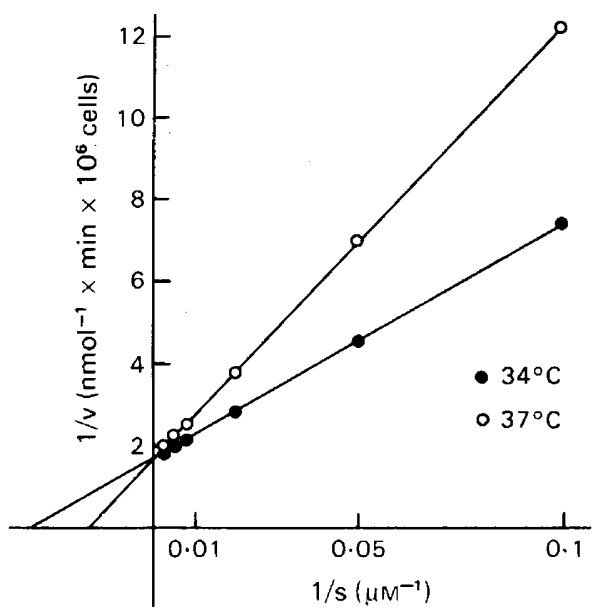

Text-fig. 4. Kinetics of transport of 3-O-methyl-D- $\left[{ }^{14} \mathrm{C}\right]$ glucose by round spermatids incubated for $1 \mathrm{~h}$. 
Influx and efflux

When influx was measured by determining transport at short intervals, values were higher at 34 than at $37^{\circ} \mathrm{C}$ (Text-fig. 5a), but when cells were incubated with 3-O-methyl-D-[ $\left.{ }^{14} \mathrm{C}\right]$ glucose for $60 \mathrm{~min}$ and transferred to medium not containing the labelled hexose, efflux of the analogue proceeded at the same rate at 34 and at $37^{\circ} \mathrm{C}$ (Text-fig. $5 \mathrm{~b}$ ). Log-log transformation of these values showed that the transformed values fitted one straight line for each temperature and that the slopes of the lines were not significantly different $(P>0 \cdot 7)$.
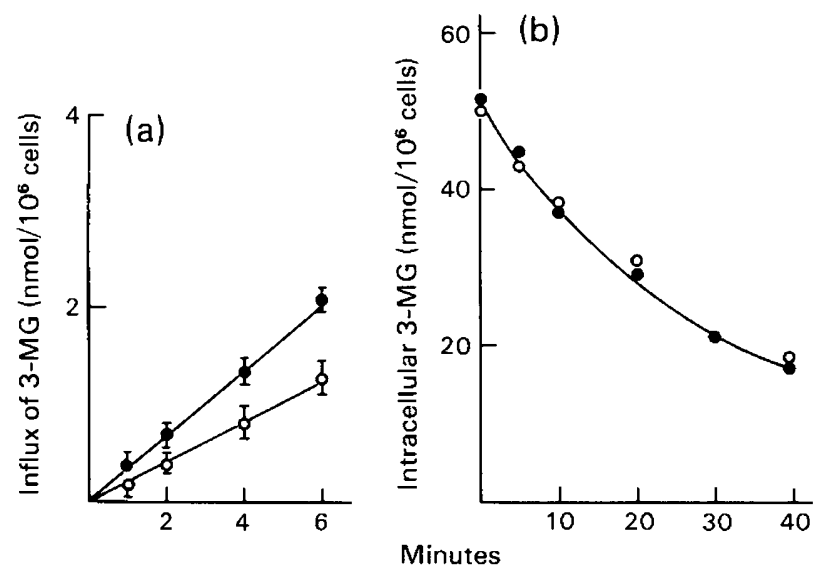

Text-fig. 5. Measurement of (a) the influx into and (b) the efflux from round spermatids of 3-O-methyl-D- $\left[{ }^{14} \mathrm{C}\right]$ glucose (3-MG). Values are means and ranges for duplicate determinations.

Transport of 3-O-methyl-D-[ $\left[{ }^{14} \mathrm{C}\right]$ glucose by a spermatocyte fraction

The enriched spermatocyte fraction consisted of spermatocytes (60\%), spermatogonia (30\%) and unidentified cells $(10 \%)$ but was devoid of spermatids. Samples of this fraction were incubated with 3-O-methyl-D- $\left[{ }^{14} \mathrm{C}\right]$ glucose at 34 and $37^{\circ} \mathrm{C}$ (Text-fig. 6). Transport of the glucose analogue was more rapid at 37 than at $34^{\circ} \mathrm{C}$.

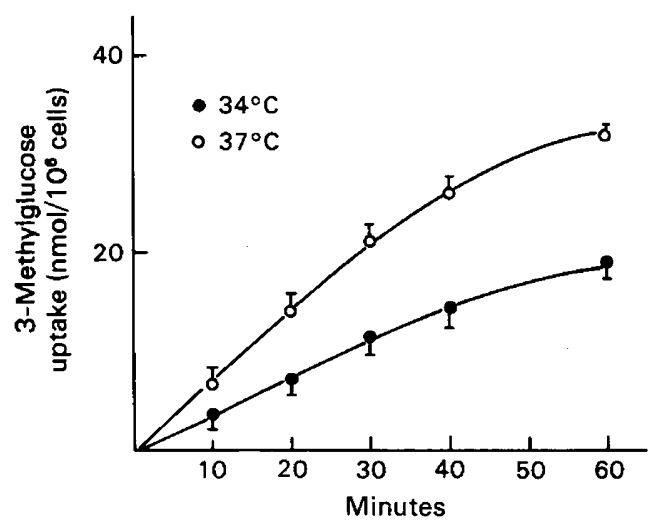

Text-fig. 6. Transport of 3-O-methyl-D- $\left[{ }^{14} \mathrm{C}\right]$ glucose by a spermatocyte-enriched fraction at two temperatures. 


\section{Discussion}

We have previously characterized pure fractions of round spermatids (Nakamura \& Hall, 1978). It was shown that these cells possess intact cell membranes as determined by electron microscopy. The findings reported here reveal that the cell membranes are intact, not only morphologically, but also functionally. The isolated spermatids are capable of active transport of hexose sugars-active in the sense that it proceeded against a concentration gradient and required high energy. Transport was linear for more than $40 \mathrm{~min}$ and was more rapid at 34 than at $37^{\circ} \mathrm{C}$ and more rapid at 37 than at $40^{\circ} \mathrm{C}$. This difference was not the result of greater cell death at $37^{\circ} \mathrm{C}$ because it could be reversed by changing the cells from 37 to $34^{\circ} \mathrm{C}$. Evidently, the spermatids continued to distinguish between the two temperatures for at least $1 \mathrm{~h}$.

The difference in transport at 37 and at $34^{\circ} \mathrm{C}$ was in $K_{\mathrm{m}}$ (concentration of substrate required for half-maximal rate of uptake) for the transport process and not in $V_{\max }$ (maximal velocity of transport), and the inhibitory effect of the higher temperature was the result of a difference in influx and not in efflux of the analogue. The effect was specific for spermatids in that a mixed fraction enriched in spermatocytes showed the conventional response to temperature, i.e. transport higher at 37 than at $34^{\circ} \mathrm{C}$. In the discussion that follows, it is assumed that the non-metabolizable hexose 3-O-methylglucose serves as a functional analogue of D-glucose as far as the transport process is concerned. Competitive inhibition of glucose transport by 3-O-methylglucose (Text-fig. 1) strongly suggested that the two sugars use the same carrier system. This view is generally accepted for other tissues (Elbrink \& Bihler, 1975). Lee (1974) has reported that spermatids developed membrane leakage at $37^{\circ} \mathrm{C}$. Such a change would be expected to produce greater efflux at 37 than at $34^{\circ} \mathrm{C}$, but this was not seen in our preparations and could be due to the centrifugal elutriation method of preparing the spermatids. We have found that the long time required to isolate spermatids by unit gravity sedimentation produces cell membrane damage (unpublished observation).

Nothing can be said at present concerning the molecular basis of the effect of temperature on the $K_{\mathrm{m}}$ for the transport process. Accessibility of the carrier molecule to the substrate may be involved rather than the number of carriers. Such a change under the influence of temperature would be entirely consistent with present views on membrane function. Presumably the unusual direction of this temperature effect in spermatids $\left(34^{\circ} \mathrm{C}>37^{\circ} \mathrm{C}\right)$ may be associated with some chemical feature of the lipid component of the spermatid cell membrane which distinguishes it from membranes of other cells.

The metabolism of many tissues, particularly testis and central nervous system, is greatly dependent upon availability of glucose (Elbrink \& Bihler, 1975). The glucose dependence of spermatids is especially pronounced (Davis \& Firlit, 1963; Means \& Hall, 1968a). A further unusual feature of the metabolic activity of the testis lies in the fact that protein synthesis is faster at 34 than at $37^{\circ} \mathrm{C}$. It is generally believed that this difference is related to and perhaps partly responsible for defective spermatogenesis at intra-abdominal temperature. The spermatids represent the principal cell type of the testis which is inhibited by body temperature (Davis \& Firlit, 1963). Moreover, several groups, including our own (Davis \& Firlit, 1963; Means \& Hall, 1968b), have shown that high concentrations of glucose protect the testis against the inhibitory effect of body temperature $\left(37^{\circ} \mathrm{C}\right)$ as opposed to scrotal temperature $\left(34^{\circ} \mathrm{C}\right)$ when protein synthesis is measured in vitro at the two temperatures. This action of glucose is due to increased production of ATP (Means \& Hall, 1968b). The regulation of glucose transport therefore assumes critical importance for the normal differentiation of spermatids.

This investigation was supported by Grant No. PCM-7822952, awarded by the National Science Foundation. 


\section{References}

Brooks, D.E. (1979) Carbohydrate metabolism in the rat epididymis: evidence that glucose is taken up by tissue slices by a process of facilitated transport. Biol. Reprod. 21, 19-26.

Davis, J.R. \& Firlit, C.R. (1963) Effect of glucose on uptake of L-lysine- ${ }^{3} \mathrm{H}$ in cells of the seminiferous epithelium. Am. J. Physiol. 209, 425-432.

Elbrink, J. \& Bihler, I. (1975) Membrane transport: its relation to cellular metabolic rates. Science, N.Y. 180, 1177-1184.

Hall, P.F. \& Koritz, S.B. (1964) The conversion of cholesterol to steroids by acetone powder of particles from bovine corpus luteum. Biochemistry, N.Y. 3, 129-134.

Hupakka, R.A. \& Hammerstedt, R.H. (1978) 2Deoxyglucose transport and phosphorylation by bovine sperm. Biol. Reprod. 19, 368-379.

Lee, L.P.K. (1974) Temperature effect on the permeability of plasma membranes of advanced germinal cells of the rat testis. Canad. J. Biochem. 52, 586-593.
Means, A.R. \& Hall, P.F. (1968a) Protein biosynthesis in the testis I: comparison between stimulation by FSH and glucose. Endocrinology 82, 597-602.

Means, A.R. \& Hall, P.F. (1968b) Protein biosynthesis in the testis II: role of adenosine triphosphate (ATP) in stimulation by glucose. Endocrinology 83, 86-96.

Nakamura, M. \& Hall, P.F. (1976) Inhibition by 5-thio-D-glucopyranose of protein biosynthesis in vitro in spermatids from rat testis. Biochim. Biophys. Acta 447, 474-483.

Nakamura, M. \& Hall, P.F. (1978) The effects of temperature and glucose on protein biosynthesis by immature (round) spermatids from rat testes. J. Cell Biol. 79, 1-9.

Paul, H.E., Paul, M.F., Kopko, F., Bender, R.C. \& Everett, G. (1953) Carbohydrate metabolism studies on the testis of rats fed certain nitrofurans. Endocrinology 53, 585-592.

Waites, G.M.H. \& Setchell, B.P. (1964) Effect of local heat on blood flow and metabolism in testis of conscious ram. J. Reprod. Fert. 8, 339-349.

Received 29 Decrmber 1980 